\title{
Surgical Management of Unilateral Partial Limbal Stem Cell Deficiency: Conjunctival Autografts versus Simple Limbal Epithelial Transplantation
}

\author{
Swapna S Shanbhag' \\ Sanjay Chanda' \\ Pragnya R Donthineni ${ }^{1}$ \\ Sayan Basu ${ }^{1-3}$
}

'The Cornea Institute, L.V. Prasad Eye Institute, Hyderabad, Telangana, India; ${ }^{2}$ Center for Ocular Regeneration (CORE), L.V. Prasad Eye Institute, Hyderabad, Telangana, India; ${ }^{3}$ Brien Holden Eye Research Centre (BHERC), L.V. Prasad Eye Institute, Hyderabad, Telangana, India
Correspondence: Sayan Basu Brien Holden Eye Research Centre (BHERC), L.V. Prasad Eye Institute, Road No. 2, Banjara Hills, Hyderabad, 500034, Telangana, India

Tel +9| 40306/2555

$\mathrm{Fax}+9 \mid$ 40-2354827।

Email sayanbasu@lvpei.org
Purpose: To evaluate the clinical outcomes of conjunctival autograft (CAG) versus simple limbal epithelial transplant (SLET) for management of unilateral partial limbal stem cell deficiency (LSCD).

Methods: This retrospective, comparative, interventional case series evaluated 30 eyes of 30 patients with unilateral partial LSCD. After corneal pannus dissection, 17 patients underwent CAG where graft was harvested from the ipsilateral or contralateral eye, while 13 patients underwent SLET where limbal biopsy was harvested from the contralateral eye. The primary outcome measure was anatomical success in the form of restoration of a completely epithelised, stable, and avascular corneal surface at last follow-up.

Results: Both groups were comparable in terms of age at time of surgery, preoperative bestcorrected visual acuity, median duration since injury, number of clock hours of limbus involved, and number of previous surgeries performed. The most common etiology for LSCD was chemical burns in both groups. The median duration of post-operative follow-up was 5.6 months [interquartile range [(IQR): 3.6-15.1] in the CAG group versus 6.2 months (IQR: 4.5-12.2) in the SLET group $(\mathrm{p}=0.75)]$. The anatomical success rates were $86.5 \pm 8.9 \%$ in the CAG group and $28.3 \pm 13.7 \%$ in the SLET group at final follow-up visit $(\mathrm{p}=0.025)$. Most failures in both groups occurred within the first 8 months after surgery.

Conclusion: For eyes with unilateral partial LSCD secondary to chemical burns, CAG is a safe and effective method for restoring the corneal epithelium. Limbal transplantation may not be necessary for the treatment of partial LSCD.

Keywords: partial limbal stem cell deficiency, ocular chemical burn, simple limbal epithelial transplantation, conjunctival autograft, symblepharon

\section{Introduction}

The ocular surface is covered by the epithelium of the cornea, the limbus, and the conjunctiva, each of which are phenotypically distinct from each other. ${ }^{1,2}$ The limbus which acts as a barrier between the conjunctival and the corneal epithelia contains limbal epithelial stem cells (LESCs) and maintains a normal epithelial turnover. ${ }^{3-5}$ Limbal damage prevents corneal epithelial wound healing and can thus precipitate into limbal stem cell deficiency (LSCD). ${ }^{6}$ Corneas with LSCD show conjunctivalization, corneal vascularization, corneal opacity, and unhealthy epithelium manifesting as persistent epithelial defects. Depending on the extent of limbus damaged, LSCD can be categorised as partial or total LSCD. 
Partial LSCD is characterized by incomplete conjunctivalization of the corneal surface and the presence of residual limbal and corneal epithelial cells. ${ }^{7}$ In corneas with partial LSCD, the complete corneal surface is not conjunctivalized and some amount of limbus is still functioning and maintaining an epithelium of the corneal phenotype on the corneal surface. ${ }^{1}$ Unilateral partial LSCD has been treated by repeated removal of the conjunctival epithelium from the corneal surface in the form of sequential sectoral conjunctival epitheliectomy (SSCE), ${ }^{8,9}$ or removal of the conjunctival epithelium from the corneal surface followed by amniotic membrane transplantation (AMT), ${ }^{10-15}$ or autologous or allogeneic limbal stem cell transplantation (LSCT) where limbus is harvested from different sources. Different LSCT techniques such as conjunctival limbal autograft (CLAu), ${ }^{16,17}$ cultivated limbal epithelial transplantation (CLET) ${ }^{18,19}$ and simple limbal epithelial transplantation (SLET) ${ }^{17,20-23}$ have been describe to treat partial LSCD.

There are two schools of thought on the treatment of partial LSCD, one that believes that transplantation of healthy limbus is necessary while the other believes that this is not necessarily required. Our hypothesis was that if the conjunctivalized corneal epithelium is debrided and detached from the cornea, and a conjunctival autograft (CAG) placed on the adjacent bare sclera where the conjunctiva has recessed, then it is possible that the healthy limbus in the recipient cornea may replenish epithelium of the corneal phenotype on the debrided area. At the same time, the CAG may act as a barrier and prevent the surrounding conjunctiva from encroaching onto the cornea. The purpose of this study was to compare the outcomes of CAG and SLET in eyes with unilateral partial LSCD where CAG was harvested from the ipsilateral or contralateral healthy conjunctiva while one clock hour of limbus was obtained from the contralateral healthy eye for SLET.

\section{Materials and Methods}

\section{Study Design, Approval and Participants}

This was a retrospective, non-randomized, interventional case series. This study was approved by the Ethics Committee of the L. V. Prasad Eye Institute, Hyderabad, India, and was conducted in strict adherence to the tenets of the Declaration of Helsinki. Prior written informed consent was obtained from all patients or guardians, as appropriate for the surgical procedure. Medical records of all patients with unilateral partial LSCD who underwent SLET or CAG between January 2016 and December 2019 were retrieved from our electronic medical record database. The diagnosis of LSCD in all cases was based on clinical characteristics. Partial LSCD was defined as superficial corneal vascularization, diffuse fluorescein staining of the corneal surface with or without persistent epithelial defects, conjunctivalization of the corneal surface extending from 3 to 9 clock hours of the limbus. Patients with unilateral pathology with no clinical signs of LSCD in the other eye were included. Patients with concomitant dry eye (Schirmer test without anaesthesia of $<10 \mathrm{~mm}$ in 5 minutes) and patients where the pathology was obviously pterygium were excluded.

\section{Data Collection}

The following preoperative parameters were collected: age and gender of the patient; etiology and duration of partial LSCD, details of prior surgeries, best-corrected visual acuity (BCVA) at presentation, and extent of limbal involvement in clock hours. Staging of LSCD for each eye was performed as per the classification given by Deng et al. ${ }^{7}$ Corneal vascularization, corneal opacity, conjunctivalization of the cornea, and symblepharon were graded as per the classification given by Sotozono et al. ${ }^{24}$ Regarding the surgery, the following details were collected: the type of surgery performed, and if tissue (limbus/conjunctiva) was harvested from ipsilateral or contralateral eye. For further follow-up visits, the following data were collected: the duration of follow-up, BCVA at final post-operative visit, and anatomical success at final post-operative visit. In cases with failure of primary surgery and recurrence of partial LSCD, the date at which the recurrence was first noted was considered as the last follow-up.

\section{Surgical Technique \\ CAG}

In the eye with partial LSCD with or without symblepharon, the fibrovascular pannus in the area of the cornea with partial LSCD was scraped off and detached at the limbus allowing the conjunctiva to recess, revealing an area of bare sclera. This area of bare sclera was measured with a calliper. A CAG was harvested from the ipsilateral or the contralateral conjunctiva, after marking the amount of tissue required, keeping the underlying tenon's tissue intact. Decision-making regarding harvesting conjunctival tissue from the ipsilateral or contralateral eye depended on the amount of the conjunctiva required and whether the conjunctiva was healthy or fibrosed. With the 
help of fibrin glue (Tisseel Kit, Baxter AG, Vienna, Austria) or 8-0 polyglactin sutures, the $\mathrm{CAG}$ was secured in the area of the bare sclera. A bandage contact lens (BCL) was placed on the cornea at the end of the surgery.

\section{SLET}

To address partial LSCD, the originally described technique of SLET for total LSCD was modified. ${ }^{25}$ In the eye with partial LSCD with or without symblepharon, the fibrovascular pannus in the area of the cornea with partial LSCD was scraped off and detached, allowing the conjunctiva to recess revealing an area of bare sclera adjacent to the cornea. The rest of the corneal epithelium was left intact. A limbal biopsy of $<1$ o'clock hour in size was harvested from the contralateral eye and cut into 4-6 small pieces. Cryopreserved amniotic membrane (AM; Ramayamma International Eye Bank, Hyderabad) was secured with fibrin glue on the de-epithelised area of cornea and on the bare sclera. The limbal pieces were arranged over the AM over the cornea and fixed with fibrin glue, and a BCL was placed on the cornea.

\section{Post-Operative Management}

The post-operative management was uniform for all cases. Topical medications included prednisolone acetate $(1 \%)$ eye drops six times daily which was tapered off and stopped after 6 weeks, and moxifloxacin eye drops $(0.4 \%)$ four times daily were given till complete epithelialisation of the ocular surface was achieved. All patients were seen at post-operative day 1 , day 7 and at 1 month. The BCL was removed at the 1 month post-operative visit in all cases. Patients were then asked to review at 3 months and 6 months post-operatively, and at six monthly intervals thereafter.

\section{Outcome Measures}

The primary outcome measure in each group was anatomical success. Anatomical success was defined as completely epithelialized, stable and avascular corneal surface at last post-operative visit. Anatomical failure was labelled when recurrence of conjunctivalization was noted on the cornea. Survival time was calculated from the date of surgery to the date of last post-operative visit for eyes with anatomical success while for eyes with anatomical failure, the follow-up visit at which failure was first noted was calculated as the last post-operative visit. Improvement in BCVA and complications, if any, were the secondary outcome measures in each group.

\section{Statistical Analysis}

The statistical analysis was performed using Stata statistical software 15 (StataCorp, College Station, Texas). Normality of the data was evaluated with the ShapiroWilk test. Baseline parameters were compared in both the groups using the Wilcoxon rank sum test for continuous non-parametric variables, the $t$-test for continuous parametric variables, and the Fisher's exact test for categorical variables. A Kaplan-Meier survival analysis was generated for anatomical outcomes, and Log rank test was performed to compare the survival curves of both groups.

\section{Results}

\section{Patient Demographics}

The study included a total of 30 eyes of 30 patients, 17 eyes underwent CAG while 13 eyes underwent SLET. The demographic details of both groups are shown in Table 1. Patients in both groups were young and there was no significant difference in the median age at which patients underwent surgery. There were more males in the group that underwent CAG as compared to the group that underwent SLET, this difference was significant $(\mathrm{p}=0.049)$. The primary etiology of partial LSCD for which patients underwent surgery were mostly ocular chemical burns in both groups, however the number of patients with alkali chemical burns were significantly higher in the group that underwent CAG $(p=0.02)$. One eye in the CAG group required an entropion correction surgery before surgical management of partial LSCD. The groups were similar in terms of duration between injury and surgery, the number of previous surgeries performed, the median preoperative visual acuity, and the mean number of clock hours of limbus involved with partial LSCD preoperatively. There were no significant differences in the preoperative ocular surface parameters such as stage of LSCD, corneal vascularization, corneal opacity, conjunctivalization, and symblepharon for the eyes in both the groups (Table 2).

\section{Surgical Characteristics}

For all patients that underwent $\mathrm{CAG}$, the graft was harvested from the same eye in nine patients and from the opposite eye in eight patients. For all patients that underwent SLET, the limbal biopsy was obtained from the contralateral eye. There was no significant difference in the post-operative follow-up duration in both groups $(\mathrm{p}=0.75)$. 
Table I Clinical Characteristics of Patients Who Underwent Treatment for Unilateral Partial Limbal Stem Cell Deficiency.

\begin{tabular}{|c|c|c|c|}
\hline Category & $\begin{array}{l}\text { Group I: Patients Who } \\
\text { Underwent Conjunctival } \\
\text { Autograft (CAG), } n=17 \\
\text { Eyes }\end{array}$ & $\begin{array}{l}\text { Group II: Patients Who } \\
\text { Underwent Simple Limbal } \\
\text { Epithelial Transplantation } \\
\text { (SLET), } n=13 \text { Eyes }\end{array}$ & $P$ value \\
\hline Median age at the time of surgery in years (IQR) & $24(16-28)$ & $32(19-37)$ & $0.21 *$ \\
\hline \multicolumn{4}{|l|}{ Gender, n (\%) } \\
\hline Male & $15(88)$ & $7(54)$ & $0.049^{\ddagger}$ \\
\hline Female & $2(12)$ & $6(46)$ & \\
\hline \multicolumn{4}{|l|}{ Etiology of partial LSCD, n (\%) } \\
\hline Alkali burn & $13(76)$ & $4(3 I)$ & $0.02^{\ddagger}$ \\
\hline Acid burn & I (6) & $4(31)$ & $0.14^{\ddagger}$ \\
\hline Chemical burn of unknown etiology & $0(0)$ & I (8) & $0.43^{\ddagger}$ \\
\hline Thermal injury & $3(18)$ & I (8) & $0.61^{\ddagger}$ \\
\hline Post OSSN removal & $0(0)$ & I (8) & $0.43^{\ddagger}$ \\
\hline Idiopathic & $0(0)$ & $2(14)$ & $0.18^{\ddagger}$ \\
\hline Median duration since injury in years (IQR) & $1.71(0.6-10)$ & $4.25(1.25-8)$ & $0.3^{*}$ \\
\hline \multicolumn{4}{|l|}{ Number of previous surgeries performed } \\
\hline None & $9(53)$ & $6(46)$ & $\mathrm{I}^{\ddagger}$ \\
\hline One & $5(29)$ & $7(54)$ & $0.26^{\ddagger}$ \\
\hline More than one & $3(18)$ & $0(0)$ & $0.24^{\ddagger}$ \\
\hline \multirow{2}{*}{$\begin{array}{l}\text { Median preoperative BCVA of operated eye in } \\
\text { logMAR (IQR) }\end{array}$} & $0.4(0.2-0.8)$ & $0.5(0.4-1)$ & \multirow[t]{2}{*}{$0.34^{*}$} \\
\hline & $\begin{array}{l}\text { Snellen equivalent: } \\
20 / 50(20 / 32 \text { to } 20 / 125)\end{array}$ & $\begin{array}{l}\text { Snellen equivalent: } \\
20 / 63(20 / 50 \text { to } 20 / 200)\end{array}$ & \\
\hline $\begin{array}{l}\text { Mean number of clock hours of limbus involved } \\
\text { preoperatively (range) }\end{array}$ & $4.76 \pm 1.79(3-8)$ & $5.62 \pm 1.98(3-8)$ & $0.23^{\dagger}$ \\
\hline Number of eyes with symblepharon & $13(76)$ & $6(46)$ & $0.13^{\ddagger}$ \\
\hline $\begin{array}{l}\text { Median post-operative follow-up duration in } \\
\text { months (IQR) }\end{array}$ & $5.6(3.6-15.1)$ & $6.2(4.5-12.2)$ & $0.75^{*}$ \\
\hline $\begin{array}{l}\text { Number of eyes with anatomical success at last } \\
\text { follow-up }\end{array}$ & $15(88)$ & $5(38)$ & $0.007^{\ddagger}$ \\
\hline \multirow{2}{*}{$\begin{array}{l}\text { Median post-operative BCVA of operated eye in } \\
\text { logMAR (IQR) }\end{array}$} & $0.2(0-0.6)$ & $0.4(0.2-0.6)$ & \multirow[t]{2}{*}{$0.48^{*}$} \\
\hline & $\begin{array}{l}\text { Snellen equivalent } \\
20 / 32(20 / 20 \text { to } 20 / 80)\end{array}$ & $\begin{array}{l}\text { Snellen equivalent } \\
20 / 50(20 / 32 \text { to } 20 / 80)\end{array}$ & \\
\hline
\end{tabular}

Notes: ${ }^{\dagger}$ t-test; $*$ Mann-Whitney U-test, ${ }^{\ddagger}$ Fisher's exact test.

Abbreviations: LSCD, limbal stem cell deficiency; BCVA, best-corrected visual acuity; OSSN, ocular surface squamous neoplasia; IQR, interquartile range.

\section{Anatomical Outcome}

At a median follow-up of 5.6 months [interquartile range (IQR): 3.6-15.1], 88\% eyes (15/17) maintained a completely epithelialized, stable, and avascular corneal surface after undergoing CAG for partial LSCD. For the eyes that underwent SLET, 38\% eyes (5/13) showed anatomical success at a median follow-up of 6.2 months (IQR: 4.5-12.2). There was a significant difference in the anatomical outcomes between both groups $(p=0.007)$. The Kaplan-Meier curves for both groups are shown in Figure 1. The anatomical success rates were $86.5 \pm 8.9 \%$ in the CAG group and $28.3 \pm 13.7 \%$ in the SLET group at the final follow-up visit $(p=0.025)$. Figure 2 shows the anatomical outcomes in eyes which underwent SLET and CAG.

\section{Visual Outcomes}

The median preoperative BCVA in both the groups was similar $(\mathrm{p}=0.34)$. There was no significant difference in the 
Table 2 Ocular Surface Characteristics Preoperatively of Patients Who Underwent Treatment for Unilateral Partial Limbal Stem Cell Deficiency.

\begin{tabular}{|c|c|c|c|}
\hline $\begin{array}{l}\text { Ocular Surface } \\
\text { Characteristics }\end{array}$ & $\begin{array}{l}\text { Group I: Patients } \\
\text { Who Underwent } \\
\text { Conjunctival } \\
\text { Autograft (CAG), } \\
\text { n = } 17 \text { Eyes (\%) }\end{array}$ & $\begin{array}{c}\text { Group II: } \\
\text { Patients Who } \\
\text { Underwent } \\
\text { Simple Limbal } \\
\text { Epithelial } \\
\text { Transplantation } \\
\text { (SLET), } n=13 \\
\text { Eyes (\%) }\end{array}$ & $P$ value \\
\hline \multicolumn{4}{|l|}{$\begin{array}{l}\text { Stage of limbal stem } \\
\text { cell deficiency }\end{array}$} \\
\hline IA & 8 (47) & $3(23)$ & 0.26 \\
\hline IB & $2(12)$ & $3(23)$ & 0.63 \\
\hline IIA & $5(29)$ & $3(23)$ & 1 \\
\hline IIB & $2(12)$ & $4(31)$ & 0.36 \\
\hline \multicolumn{4}{|l|}{$\begin{array}{l}\text { Corneal } \\
\text { vascularization }{ }^{\mathrm{b}}\end{array}$} \\
\hline 0 & $0(0)$ & $0(0)$ & \\
\hline 1 & $5(29)$ & $3(23)$ & 1 \\
\hline 2 & $12(7 I)$ & $10(77)$ & 1 \\
\hline 3 & $0(0)$ & $0(0)$ & \\
\hline \multicolumn{4}{|l|}{ Corneal opacity } \\
\hline 0 & $0(0)$ & $0(0)$ & \\
\hline 1 & $13(76)$ & II (85) & 0.67 \\
\hline 2 & $4(24)$ & $2(15)$ & 0.67 \\
\hline 3 & $0(0)$ & $0(0)$ & \\
\hline \multicolumn{4}{|l|}{ Conjunctivalization ${ }^{\mathrm{b}}$} \\
\hline 0 & $0(0)$ & $0(0)$ & \\
\hline 1 & $5(29)$ & $0(0)$ & 0.052 \\
\hline 2 & $10(59)$ & $9(69)$ & 0.71 \\
\hline 3 & $2(12)$ & $4(31)$ & 0.36 \\
\hline \multicolumn{4}{|l|}{ Symblepharon ${ }^{\mathrm{b}}$} \\
\hline 0 & $4(24)$ & $7(54)$ & 0.13 \\
\hline 1 & I (6) & $3(23)$ & 0.29 \\
\hline 2 & $9(53)$ & $3(23)$ & 0.14 \\
\hline 3 & $3(17)$ & $0(0)$ & 0.24 \\
\hline
\end{tabular}

Notes: a'Staging as per Deng SX, Borderie V, Chan CC; and The International Limbal Stem Cell Deficiency Working Group. Global Consensus on Definition, Classification, Diagnosis, and Staging of Limbal Stem Cell Deficiency. Cornea. 2019;38:364-375. 'brading as per Sotozono C, Ang LP, Koizumi $\mathrm{N}$ et al. New grading system for the evaluation of chronic ocular manifestations in patients with Stevens-Johnson syndrome. Ophthalmology. 2007;1 14:1294-302.

median post-operative BCVA in both the groups $(p=0.48)$. In the CAG group, the median preoperative BCVA was 20/ 50 while the median post-operative BCVA was 20/32. The improvement in vision was significant $(p=0.007)$. Of those, eleven eyes $(65 \%)$ gained $\geq$ two lines, two eyes gained one line, and one eye lost four lines of Snellen acuity. In three eyes, there was no change in visual acuity.

In the group where eyes underwent SLET, the median preoperative BCVA was 20/63 while the median post- operative BCVA was 20/50. The improvement in vision was significant $(\mathrm{p}=0.03)$. Of those, nine eyes $(69 \%)$ gained $\geq$ two lines, two eyes gained one line, while two eyes showed no change in visual acuity.

\section{Complications}

No intraoperative complications were noted in either group during CAG harvest or during limbal biopsy. In the eyes that underwent SLET, none of the eyes showed any evidence of iatrogenic LSCD at the site from where limbal biopsy was harvested. In the two eyes with failure in the CAG group, the conjunctival graft was lost at post-operative 1 week in one eye, while conjunctivalization over the cornea recurred resulting into partial LSCD in one eye. The two cases that failed had LSCD secondary to alkali burn in one eye, and acid burn in the second eye. In the eight eyes with failure in the SLET group, all eight eyes had recurrence of conjunctivalization over the cornea. Of the eight cases that failed, three had LSCD secondary to alkali burn, two secondary to acid burn, two had LSCD secondary to idiopathic etiology, and one had LSCD post ocular surface squamous neoplasia excision. The Kaplan-Meier survival curves (Figure 1) show that a majority of failures in both groups occurred within the first 8 months after surgical intervention.

\section{Discussion}

Partial LSCD has been shown to contribute to one-third cases of LSCD. ${ }^{26}$ Although the treatment strategies for unilateral total LSCD are quite straightforward, ${ }^{27}$ the same is not true for the treatment of unilateral partial LSCD. Treatment modalities for unilateral partial LSCD range from repeatedly debriding the conjunctival epithelium on the cornea in the form of SSCE to autologous and allogeneic LSCT. ${ }^{9,10,16,19,28,29}$ We conducted this study to compare the outcomes of placing a CAG on the bare sclera adjacent to the area of partial LSCD versus SLET where limbal transplants from the opposite eye are placed on the cornea from where the conjunctival tissue has been debrided.

This study found that in eyes with unilateral partial LSCD, the etiology being chemical burns in the majority of eyes, the recurrence of LSCD was lower in eyes that underwent $\mathrm{CAG}$ as compared to SLET. CAG is easily accessible from the ipsilateral or contralateral eye, does not require any processing post-harvest and is inexpensive. There is no damage to the limbal tissue nor is systemic immunosuppression required. Thus, CAG could 


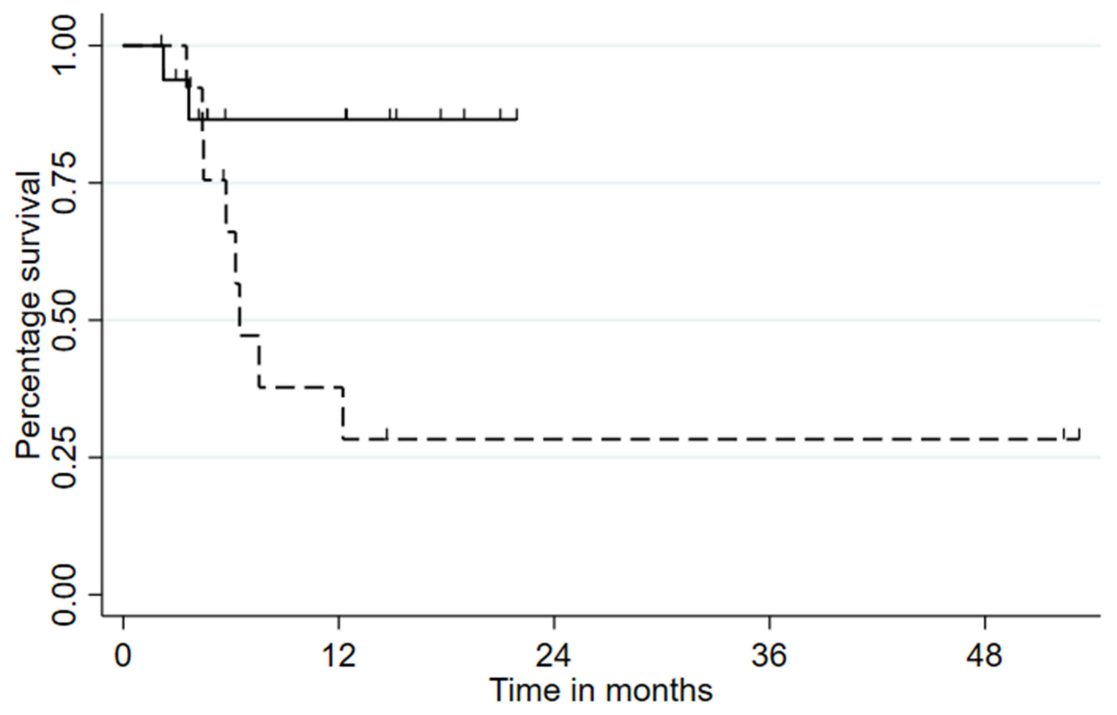

$\begin{array}{rrrrrr}\text { Number at risk } & & & & \\ \text { CAG } & 17 & 8 & 0 & 0 & 0 \\ \text { SLET } & 13 & 4 & 2 & 2 & 2 \\ & & & \text { CAG } & \text { - CA-- SLET }\end{array}$

Figure I Kaplan-Meier survival curves showing the probability of success of conjunctival autograft ( 17 eyes) versus simple limbal epithelial transplantation ( 13 eyes) in eyes with unilateral partial limbal stem cell deficiency. The survival curves for the two groups are significantly different $(p=0.025)$.

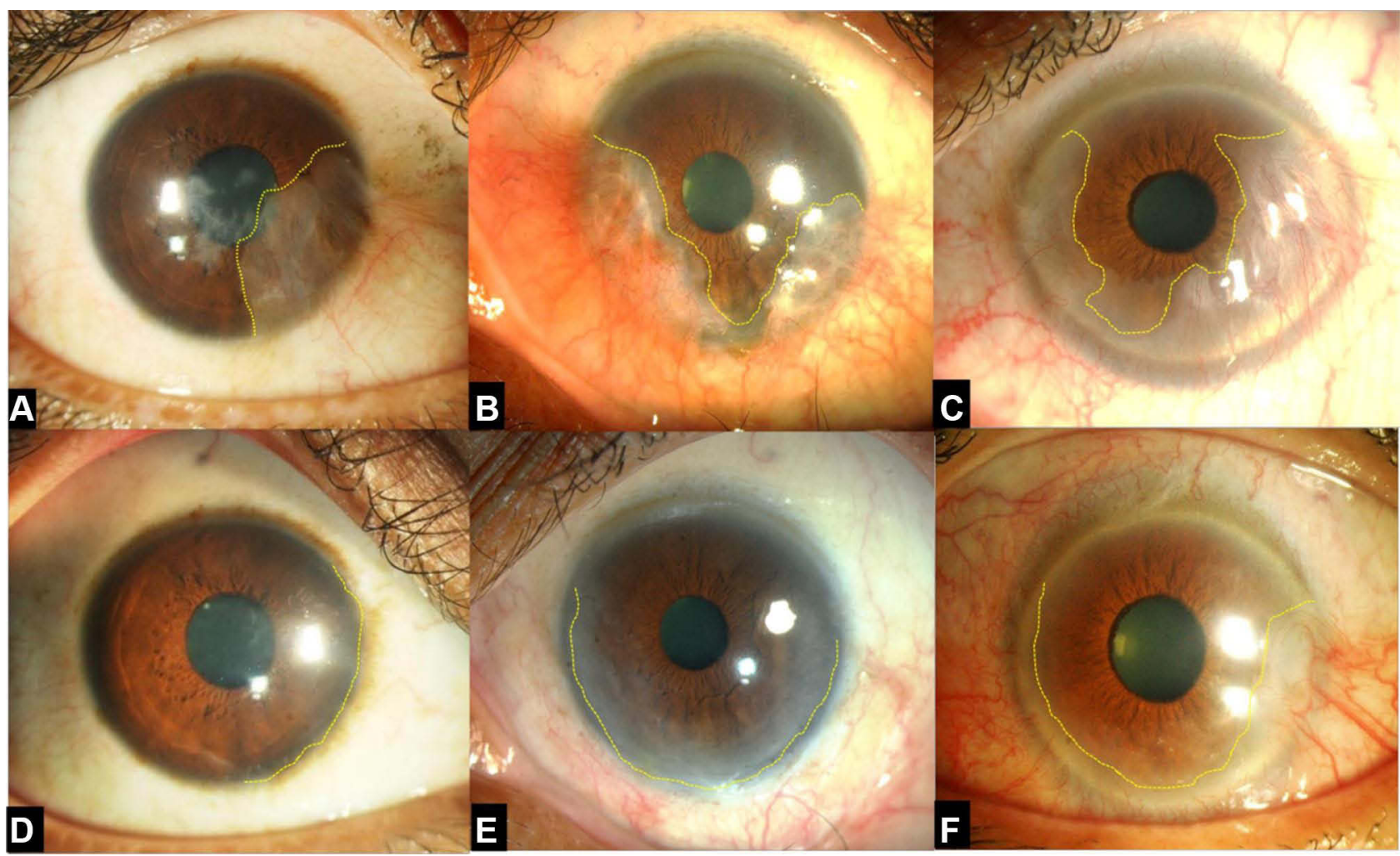

Figure 2 Outcomes of conjunctival autograft (CAG) and simple limbal epithelial transplantation (SLET) in eyes with unilateral partial limbal stem cell deficiency (LSCD). The top row shows preoperative photos of patients with unilateral partial LSCD (A-C). For the first two eyes (A and B), the patient underwent CAG with a successful outcome and no recurrence of LSCD (D and E). For the third eye (C), the patient underwent SLET with recurrence of LSCD in the temporal quadrant $(\mathbf{F})$. 
be a safer and effective alternative to AMT or LSCT for treatment of unilateral partial LSCD. Table 3 provides an overall comparison of the results of this study with results of other larger series where unilateral partial LSCD has been treated for the etiology of ocular chemical burns. All surgical techniques described for unilateral partial LSCD have their own advantages and disadvantages. SSCE requires multiple visits, may be painful to the patient, and outcomes of SSCE have not been published yet. ${ }^{9}$ AMT for reconstruction of the corneal surface in eyes with partial LSCD has favourable outcomes. ${ }^{10,30}$ The success of AMT in these eyes shows that limbal tissue in the form of autologous or allogeneic LSCT may not be required in eyes with partial LSCD. This avoids the risk of iatrogenic LSCD to the donor eye or the need for systemic immunosuppression. However, $\mathrm{AM}$ is not a readily available tissue and requires significant technological advances to be able to procure and preserve it, thus increasing the cost to the patient. Hence, AM may not be the treatment of choice for partial LSCD in countries where it is not readily available or for patients who may not be able to afford it. Ipsilateral and contralateral CLAU, ipsilateral and contralateral CLET, and allogeneic LSCT in the form of livingrelated conjunctival limbal allograft have all shown favourable outcomes in eyes with partial LSCD. ${ }^{16,17,19,28}$ However, these modalities may either increase the risk of iatrogenic LSCD or may be expensive as in-vivo expansion of epithelial cells is required, or systemic immunosuppression may be required.

Table 3 Outcomes of Different Surgical Techniques for Treatment of Unilateral Partial Limbal Stem Cell Deficiency.

\begin{tabular}{|c|c|c|c|c|c|c|c|c|c|}
\hline S. No & Author & Year & Country & $\begin{array}{l}\text { Number } \\
\text { of Eyes } \\
\text { (Patients) }\end{array}$ & $\begin{array}{l}\text { Number of Eyes } \\
\text { with Etiology of } \\
\text { Chemical/Thermal } \\
\text { Burns }\end{array}$ & $\begin{array}{l}\text { Surgical } \\
\text { Intervention* }\end{array}$ & $\begin{array}{l}\text { Number of } \\
\text { Eyes with } \\
\text { Anatomical } \\
\text { Success (\%) }\end{array}$ & $\begin{array}{l}\text { Number of Eyes with } \\
\geq 2 \text { Lines of } \\
\text { Improvement in Visual } \\
\text { Acuity (\%) }\end{array}$ & $\begin{array}{l}\text { Follow- } \\
\text { Up in } \\
\text { Months }\end{array}$ \\
\hline 1 & $\begin{array}{l}\text { Anderson } \\
\text { et al }{ }^{10}\end{array}$ & 2001 & USA & $17(15)$ & 8 & AMT alone & $17(100)$ & $10(59)$ & $\begin{array}{l}\text { Mean - } \\
25.8\end{array}$ \\
\hline 2 & $\begin{array}{l}\text { Nishiwaki- } \\
\text { Dantas } \\
\text { et al }{ }^{16}\end{array}$ & 2001 & Brazil & $5(5)$ & 5 & $\begin{array}{l}\text { CLAu } \\
\text { (ipsilateral - } \\
2.5 \times 5 \mathrm{~mm} \\
\text { limbus) }\end{array}$ & $5(100)$ & $5(100)$ & $\begin{array}{l}\text { Mean - } \\
8.8\end{array}$ \\
\hline 3 & $\begin{array}{l}\text { Huang } \\
\text { et } \mathrm{al}^{28}\end{array}$ & 2011 & China & $5(5)$ & 5 & $\begin{array}{l}\text { CLAL (4-5 } \\
\text { clock hours of } \\
\text { limbus) }\end{array}$ & $2(40)^{\#}$ & $5(100)$ & $\begin{array}{l}\text { Mean - } \\
20\end{array}$ \\
\hline 4 & $\begin{array}{l}\text { Vazirani } \\
\text { et al }{ }^{19}\end{array}$ & 2014 & India & $34(34)$ & 31 & $\begin{array}{l}\text { CLET } \\
\text { (ipsilateral - }<2 \\
\text { clock hours of } \\
\text { limbus) }\end{array}$ & 24 (7I) & ND & $\begin{array}{l}\text { Mean - } \\
17.5^{\mathrm{a}}\end{array}$ \\
\hline 5 & $\begin{array}{l}\text { Vazirani } \\
\text { et al }{ }^{19}\end{array}$ & 2014 & India & $36(36)$ & 33 & $\begin{array}{l}\text { CLET } \\
\text { (contralateral - } \\
<2 \text { clock hours } \\
\text { of limbus) }\end{array}$ & $27(75)$ & ND & $\begin{array}{l}\text { Mean - } \\
17.5^{\mathrm{a}}\end{array}$ \\
\hline 6 & $\begin{array}{l}\text { Cheng } \\
\text { et } \mathrm{a}^{29}\end{array}$ & 2017 & China & $23(23)$ & 23 & $\begin{array}{l}\text { Allogeneic } \\
\text { CLET } \\
\text { (cadaveric) }\end{array}$ & $12(52)$ & ND & $\begin{array}{l}\text { Mean - } \\
26.4^{\mathrm{a}}\end{array}$ \\
\hline 7 & $\begin{array}{l}\text { Chanda } \\
\text { et al }\end{array}$ & 2021 & India & $17(17)$ & 17 & $\begin{array}{l}\text { Conjunctival } \\
\text { autograft }\end{array}$ & $15(88)$ & $11(65)$ & $\begin{array}{l}\text { Median - } \\
5.6\end{array}$ \\
\hline 8 & $\begin{array}{l}\text { Chanda } \\
\text { et al }\end{array}$ & 2021 & India & $13(13)$ & 10 & $\begin{array}{l}\text { SLET (I } \\
\text { clock hour of } \\
\text { limbus) }\end{array}$ & $5(38)$ & $9(69)$ & $\begin{array}{l}\text { Median - } \\
6.2\end{array}$ \\
\hline
\end{tabular}

Notes: *For each intervention, studies with maximum eyes with etiology of chemical burns selected, where anatomical outcomes could be evaluated in eyes with partial limbal stem cell deficiency. ${ }^{\#}$ Recurrence of peripheral corneal neovascularization noted 7-10 months after surgery. ${ }^{\mathrm{a} F o l l o w-u p ~ p e r i o d ~ n o t ~ s p e c i f i c ~ t o ~ t h i s ~ c o h o r t . ~}$

Abbreviations: AMT, amniotic membrane transplantation; CLAu, conjunctival-limbal autograft; CLAL, conjunctival-limbal allograft; CLET, cultivated limbal epithelial transplantation; SLET, simple limbal epithelial transplantation; ND, not documented. 
In eyes that underwent SLET for total LSCD, eyes with pre-existing symblepharon have shown higher rates of failure with subsequent conjunctivalization of cornea in the area of maximum preoperative symblepharon..$^{20,21,31}$ Mittal et al attributed this to extensive primary conjunctival damage and addressed this recurrent conjunctivalization of cornea by performing CAG with repeat SLET with favourable outcomes. Simultaneous SLET with CAG has also been documented in eyes with total LSCD with symblepharon, showing excellent results. ${ }^{32}$ Hence, we believe repeat SLET may not be required in these eyes and only CAG can be performed to address the focal recurrence of LSCD. Similarly, CAG may be an effective treatment modality in eyes with partial LSCD where it functions by providing a barrier to prevent the conjunctiva from encroaching onto the cornea while the remaining intact limbus provides the epithelial cells that migrate over the denuded cornea, and an additional basement membrane such as AM may not be necessary to aid with epithelial cell adhesion and migration. In eyes with partial LSCD combined with symblepharon, the symblepharon may be a healing response to the deficiency in the conjunctival tissue, and CAG has an additional function in these eyes by addressing the conjunctival deficiency. Adding additional stem cells to the mix in the form of SLET may not provide any added advantage in these eyes where the limbus is already intact in some areas and may have the potential to regenerate the remaining epithelium of corneal phenotype. The pathology of partial LSCD is remarkably similar to pterygium. Performing CAG after excising pterygium has shown the lowest recurrence rates after 6 months in comparison with other techniques such as AMT. ${ }^{33-35}$ Hence, we believe that CAG may be the best treatment modality available for treating eyes with partial LSCD too.

The strengths of the study are that it is a comparative analysis between two surgical procedures with most eyes having similar etiologies for partial LSCD. All the surgeries were performed by experienced ocular surface surgeons and there was no case selection bias in terms of severity of LSCD. This study however has the limitations of being a retrospective study, having a small sample size and relatively short follow-up. Most patients who seek treatment for partial LSCD do so for cosmetic purposes and may not be motivated to follow-up for a longer period once the goal of cosmesis is achieved. Another limitation is that the diagnosis of LSCD was clinical in all eyes and no objective investigations were performed, and restoration of corneal phenotype postsurgery was not objectively assessed. Also, a randomized controlled trial may be more appropriate for answering the question if limbal transplantation is necessary for treating partial LSCD. However, partial LSCD is an uncommon pathology and a randomized controlled trial may require large numbers to achieve statistical significance, thus prolonging the time taken to complete such a study.

The authors conclude that CAG has reduced recurrence rates in eyes with unilateral partial LSCD in comparison to SLET. LSCT or AMT in these eyes may not be necessary. Hence, the treatment of unilateral partial LSCD may become accessible to developing countries and patients who might not be able to afford other treatment options.

\section{Funding}

This work was funded by the Hyderabad Eye Research Foundation, Hyderabad, India. The funding organisation had no role in the design or conduct of this research.

\section{Disclosure}

The authors report no conflicts of interest in this work.

\section{References}

1. Chen JJ, Tseng SC. Corneal epithelial wound healing in partial limbal deficiency. Invest Ophthalmol Vis Sci. 1990;31:1301-1314.

2. Kinoshita S, Kiorpes TC, Friend J, et al. Limbal epithelium in ocular surface wound healing. Invest Ophthalmol Vis Sci. 1982;23:73-80.

3. Schermer A, Galvin S, Sun TT. Differentiation-related expression of a major $64 \mathrm{~K}$ corneal keratin in vivo and in culture suggests limbal location of corneal epithelial stem cells. J Cell Biol. 1986;103:49-62. doi: $10.1083 /$ jcb.103.1.49

4. Cotsarelis G, Cheng SZ, Dong G, et al. Existence of slow-cycling limbal epithelial basal cells that can be preferentially stimulated to proliferate: implications on epithelial stem cells. Cell. 1989;57:201-209. doi:10.1016/0092-8674(89)90958-6

5. Thoft RA, Wiley LA, Sundarraj N. The multipotential cells of the limbus. Eye (Lond). 1989;3:109-113. doi:10.1038/eye.1989.17

6. Dua HS, Saini JS, Azuara-Blanco A, et al. Limbal stem cell deficiency: concept, aetiology, clinical presentation, diagnosis and management. Indian J Ophthalmol. 2000;48:83-92.

7. Deng SX, Borderie V, Chan CC, et al. Global consensus on definition, classification, diagnosis, and staging of limbal stem cell deficiency. Cornea. 2019;38:364-375. doi:10.1097/ICO.0000000 000001820

8. Dua HS. The conjunctiva in corneal epithelial wound healing. $\mathrm{Br}$ J Ophthalmol. 1998;82:1407-1411. doi:10.1136/bjo.82.12.1407

9. Dua HS. Sequential sector conjunctival epitheliectomy (SSCE). In: Holland EJ, Mannis MJ, editor. Ocular Surface Disease: Medical and Surgical Management. New York: Springer; 2002:168-174.

10. Anderson DF, Ellies P, Pires RT, et al. Amniotic membrane transplantation for partial limbal stem cell deficiency. $\mathrm{Br} J$ Ophthalmol. 2001;85:567-575. doi:10.1136/bjo.85.5.567 
11. Gomes JA, dos Santos MS, Cunha MC, et al. Amniotic membrane transplantation for partial and total limbal stem cell deficiency secondary to chemical burn. Ophthalmology. 2003;110:466-473. doi:10.1016/S0161-6420(02)01888-2

12. Sangwan VS, Matalia HP, Vemuganti GK, et al. Amniotic membrane transplantation for reconstruction of corneal epithelial surface in cases of partial limbal stem cell deficiency. Indian J Ophthalmol. 2004;52(4):281-285.

13. Kheirkhah A, Casas V, Raju VK, et al. Sutureless amniotic membrane transplantation for partial limbal stem cell deficiency. Am J Ophthalmol. 2008;145:787-794. doi:10.1016/j.ajo.2008.01.009

14. Konomi K, Satake Y, Shimmura S, et al. Long-term results of amniotic membrane transplantation for partial limbal deficiency. Cornea. 2013;32:1110-1115. doi:10.1097/ICO.0b013e31828d06d2

15. Chugh JP, Jain P, Sen R. Comparative analysis of fresh and dry preserved amniotic membrane transplantation in partial limbal stem cell deficiency. Int Ophthalmol. 2015;35:347-355. doi:10.1007/ s10792-014-9954-4

16. Nishiwaki-Dantas MC, Dantas PE, Reggi JR. Ipsilateral limbal translocation for treatment of partial limbal deficiency secondary to ocular alkali burn. Br J Ophthalmol. 2001;85:1031-1033. doi:10.1136/ bjo.85.9.1031

17. Arora R, Dokania P, Manudhane A, et al. Preliminary results from the comparison of simple limbal epithelial transplantation with conjunctival limbal autologous transplantation in severe unilateral chronic ocular burns. Indian J Ophthalmol. 2017;65:35-40. doi:10.4103/ 0301-4738.202312

18. Sangwan VS, Matalia HP, Vemuganti GK, et al. Clinical outcome of autologous cultivated limbal epithelium transplantation. Indian J Ophthalmol. 2006;54:29-34. doi:10.4103/0301-4738.21611

19. Vazirani J, Basu S, Kenia H, et al. Unilateral partial limbal stem cell deficiency: contralateral versus ipsilateral autologous cultivated limbal epithelial transplantation. Am J Ophthalmol. 2014;157:584-90. e1-2. doi:10.1016/j.ajo.2013.11.011

20. Basu S, Sureka SP, Shanbhag SS, et al. Simple limbal epithelial transplantation: long-term clinical outcomes in 125 cases of unilateral chronic ocular surface burns. Ophthalmology. 2016;123:1000-1010. doi:10.1016/j.ophtha.2015.12.042

21. Vazirani J, Ali MH, Sharma N, et al. Autologous simple limbal epithelial transplantation for unilateral limbal stem cell deficiency: multicentre results. $\mathrm{Br} J$ Ophthalmol. 2016;100:1416-1420. doi:10.1136/bjophthalmol-2015-307348

22. Gupta N, Joshi J, Farooqui JH, Mathur U. Results of simple limbal epithelial transplantation in unilateral ocular surface burn. Indian J Ophthalmol. 2018;66:45-52. doi:10.4103/ijo.IJO_602_17

23. Shanbhag SS, Patel CN, Goyal R, et al. Simple limbal epithelial transplantation (SLET): review of indications, surgical technique, mechanism, outcomes, limitations, and impact. Indian J Ophthalmol. 2019;67:1265-1277. doi:10.4103/ijo.IJO_117_19
24. Sotozono C, Ang LP, Koizumi N, et al. New grading system for the evaluation of chronic ocular manifestations in patients with Stevens-Johnson $\quad$ syndrome. Ophthalmology. 2007;114 (7):1294-1302. doi:10.1016/j.ophtha.2006.10.029

25. Sangwan VS, Basu S, MacNeil S, Balasubramanian D. Simple limbal epithelial transplantation (SLET): a novel surgical technique for the treatment of unilateral limbal stem cell deficiency. Br J Ophthalmol. 2012;96:931-934. doi:10.1136/bjophthalmol-2011-301164

26. Vazirani J, Nair D, Shanbhag S, et al. Limbal stem cell deficiency-demography and underlying causes. Am J Ophthalmol. 2018;188:99-103. doi:10.1016/j.ajo.2018.01.020

27. Shanbhag SS, Nikpoor N, Rao Donthineni P, et al. Autologous limbal stem cell transplantation: a systematic review of clinical outcomes with different surgical techniques. $\mathrm{Br} J$ Ophthalmol. 2020;104:247-253. doi:10.1136/bjophthalmol-2019-314081

28. Huang $T$, Wang $Y$, Zhang $H$, et al. Limbal allografting from living-related donors to treat partial limbal deficiency secondary to ocular chemical burns. Arch Ophthalmol. 2011;129:1267-1273. doi:10.1001/archophthalmol.2011.251

29. Cheng J, Zhai H, Wang J, et al. Long-term outcome of allogeneic cultivated limbal epithelial transplantation for symblepharon caused by severe ocular burns. BMC Ophthalmol. 2017;17:8. doi:10.1186/ s12886-017-0403-9

30. Le Q, Deng SX. The application of human amniotic membrane in the surgical management of limbal stem cell deficiency. Ocul Surf. 2019;17:221-229. doi:10.1016/j.jtos.2019.01.003

31. Mittal V, Jain R, Mittal R, et al. Successful management of severe unilateral chemical burns in children using simple limbal epithelial transplantation (SLET). Br J Ophthalmol. 2016;100:1102-1108. doi:10.1136/bjophthalmol-2015-307179

32. Shanbhag SS, Tarini S, Kunapuli A, et al. Simultaneous surgical management of unilateral limbal stem cell deficiency and symblepharon post chemical burn. BMJ Case Rep. 2020;13(12):e237234. doi:10.1136/bcr-2020-237234

33. Kaufman SC, Jacobs DS, Lee WB, et al. Options and adjuvants in surgery for pterygium: a report by the American Academy of Ophthalmology. Ophthalmology. 2013;120:201-208. doi:10.1016/j. ophtha.2012.06.066

34. Clearfield E, Hawkins BS, Kuo IC. Conjunctival autograft versus amniotic membrane transplantation for treatment of pterygium: findings from a Cochrane systematic review. Am J Ophthalmol. 2017;182:8-17. doi:10.1016/j.ajo.2017.07.004

35. Fonseca EC, Rocha EM, Arruda GV. Comparison among adjuvant treatments for primary pterygium: a network meta-analysis. $\mathrm{Br}$ J Ophthalmol. 2018;102:748-756. doi:10.1136/bjophthalmol-2017310288
Clinical Ophthalmology

\section{Publish your work in this journal}

Clinical Ophthalmology is an international, peer-reviewed journal covering all subspecialties within ophthalmology. Key topics include: Optometry; Visual science; Pharmacology and drug therapy in eye diseases; Basic Sciences; Primary and Secondary eye care; Patient Safety and Quality of Care Improvements. This journal is indexed on PubMed
Central and CAS, and is the official journal of The Society of Clinical Ophthalmology (SCO). The manuscript management system is completely online and includes a very quick and fair peer-review system, which is all easy to use. Visit http://www.dovepress.com/ testimonials.php to read real quotes from published authors. 